\title{
Yunus Emre'yi Anlatan Çocuk Kitapları Üzerine Bir İnceleme
}

\author{
A Review on Children's Books Telling about Yunus Emre
}

\author{
Dr. Öğr. Üyesi Nuran BAȘOĞLUiD 1
}

\begin{abstract}
$\ddot{\mathbf{O} z}$
Araştırmada, 1960-2020 yılları arasında Yunus Emre'yi anlatan çocuk kitapları belirlenmiş ve bu anlatımın nasıl gerçekleştirildiği değerlendirilmeye çalışılmıştır. Yunus Emre menkıbelerinin ve şiirlerinin eserlerde nasıl yer bulduğu seçkisiz örnekleme yoluyla belirlenen yedi kitap üzerinden sunulmuştur. Doküman incelemesi yapılarak elde edilen veriler içerik analizi ile çözümlenmiştir. Araştırmada incelenen Yunus Emre'yi anlatan çocuk kitaplarının hepsinde Yunus Emre dünyaya geldiğinde Anadolu halkının içinde bulunduğu zor şartlara, yoksulluğa değinildiği görülmüștür. Yunus Emre'nin Hacı Bektaş-i Veli'nin kapısında bulamadığı himmeti Tapduk Emre'de bulması ve onun talebesi olması tüm kitaplarda işlenmiştir. Kitaplarda Yunus Emre'nin en çok bilinen şiirlerine yer verilmiștir. Siirlerinin yanı sıra șiirlerinden alınan beyitlere/dörtlüklere ve Yunus Emre için başka şairler tarafından kaleme alınan șiirlere de yer verilmiștir. Yunus Emre'nin menkıbevi hayatı çocukların dikkatini çekecek şekillerde kurgulara yerleştirilerek sunulmuştur. Kitaplarda menkıbeler anlatıma derinlik katarken, şiirler ve şiir parçaları sayesinde estetik bir üslup yakalanmıştır. Kitaplarda Yunus Emre'nin insan sevgisi işlenmiş ve birçok ilimizde mezarının olduğu vurgulanmıştır. Kitaplarda çocukların özdeşim kurmasını kolaylaştırmak adına kurgulara çocuk karakterlerin eklendiği görülmüştür. Yunus Emre'yi çocuklara anlatan dede, baba, öğretmen gibi yetişkin karakterlere de yer verilmiştir. Kitapların çoğunda Risaletü'n Nushiyye hakkında bilgi verilmiş, Yunus Emre felsefesi aktarılmaya çalışılmıştır.
\end{abstract}

Anahtar Kelimeler: Yunus Emre, çocuk kitapları, çocuk edebiyatı

Makale Türü: Araştırma

\begin{abstract}
In the research, children's books about Yunus Emre between 1960 and 2020 were determined and it was tried to evaluate how this narrative was carried out. How Yunus Emre's legends and poems took place in the works was presented through seven books determined by random sampling. In all of the children's books about Yunus Emre examined in the research, it was seen that the difficult conditions and poverty of the Anatolian people were mentioned when Yunus Emre was born. It is mentioned in all the books that Yunus Emre found the help he could not find at the door of Hacı Bektaş-i Veli in Tapduk Emre and that he became his student. The best-known poems of Yunus Emre are included in the books. In addition to his poems, couplets/quatrains taken from his poems and poems written by other poets for Yunus Emre are also included. Yunus Emre's legendary life is presented by placing it in fictions in ways that will attract the attention of children. While the legends add depth to the narrative in the books, an aesthetic style has been captured thanks to the poems and pieces of poetry. In the books, Yunus Emre's love for humanity has been handled and it has been emphasized that he has graves in many cities. In the books, it has been seen that children's characters are added to the fictions in order to make it easier for children to identify. Adult characters such as grandfather, father and teacher who tell Yunus Emre to children are also included. In most of the books, information about Risaletü'n Nushiyye is given and Yunus Emre's philosophy is tried to be conveyed.
\end{abstract}

Keywords: Yunus Emre, children's books, children's literature

Paper Type: Research

Zonguldak Bülent Ecevit Üniversitesi, Ereğli Eğitim Fakültesi, Türkçe ve Sosyal Bilimler Eğitimi Bölümü,
nuranbasoglu@beun.edu.tr

Atıf için (to cite): Başoğlu, N. (2021). Yunus Emre’yi anlatan çocuk kitapları üzerine bir inceleme. Afyon Kocatepe Üniversitesi Sosyal Bilimler Dergisi, 23(Yunus Emre ve Türkçe Özel Sayısı), 169-180. 


\section{Giriş}

Çocukların olay, olgu ve durumların sanatçı bakış açısıyla yorumlanmasına tanık oldukları görsel ve yazılı araçlar olan çocuk kitapları (Sever, 2007); iç yapı özellikleri, dış yapı özellikleri ve eğitim ilkeleri bakımından çocuk dünyasına uygun nitelikte hazırlanmalıdır. "Çocuğu hedef alarak kaleme alınan eserler ona görüp izlediklerini, dinlediklerini tam ve doğru olarak anlama ve anlatma gücü kazandırmalı ve çocuğun düşünme yollarını açmalıdır." (Temizyürek vd., 2016, s.23). Şirin'e göre (2007, s.23) iyi bir çocuk kitabı; çocuk gelişimine dayalı, çocuğun içinde doğduğu ve yaşadığı toplumun kültürel değerlerinden soyutlanmadan, kendini tanımasına ve sorunlarıyla yüzleşmesine, eğitimine ve gelişmesine, edebiyat ve sanat açısından desteklenmesine katkı veren özellikler içerir.

Çocuk kitaplarında; edebiyat, tarih, bilim, sanat, felsefe, spor gibi alanlarda değerli şahsiyetlerin hayatlarına biyografi türünde veya öyküleştirilerek kurgu içinde yer verilmesi çocukların kültürel anlamda zenginleşmesini sağlayabilir. Çocuk edebiyatı türleri arasında biyografinin ayrı bir yeri bulunmaktadır. Çocukların belli dönemlerde ünlü kişileri model alma yoluyla özdeşleşme duygularını doyurmaya çalıştıklarını belirten Tanju (2013); biyografilerin çocuklara başkalarının hayat kavgalarını, karşılaştıkları türlü sorunları ve başarılarının nedenlerini anlatarak, onları ileride karşılaşabilecekleri durumlara hazırladığını belirtir. Örnek kişilerin hayatlarını çocuklara tanıtmak; bilim sevgisi, sanat ve insanlık aşkı, memleket sevgisi, yiğitlik ve cesaret, hakkı savunma gibi soylu duygulara sahip vatandaşların yetişmesini destekler. Yurt ve dünya değerlerini tanımakla çocuğun kültürü de artmış olur. Biyografi türü, gerçeğe dayanır; bu sayede çocuklara tanıtılan kişinin çevresini, devrini, hayatını öğretir (Gökşen, 1980).

Yalçın ve Aytaş'a göre (2011), çocuklar biyografileri tıpkı bir hikâye gibi okudukları için biyografinin mümkün olduğu kadar anlatılan kişinin hayatındaki akıcı unsurlardan seçilmesi gerekir ve yazar çocuğu anlattığı kişi ve onun yaşadığı çevrenin içine çekebilmelidir. Çocuklar için yazılan bu eserlerde çocukların önemli şahsiyetleri tanımaları ve onlardan ilham almaları amaçlanır. Bu amaçlarla son zamanlarda yayınevleri tarafından sıklıkla çocuklar için "Ünlü Türk Büyükleri, Ünlü Düşünürler, Tarihi Yeniden Yazan Türk Büyükleri, Ünlülerle Bir Gün, Büyük Âlimler" gibi önemli şahsiyetleri tanıtan setler hazırlanmaktadır. Yunus Emre'den Mevlana'ya, Mehmet Akif'ten Mimar Sinan'a birçok önemli şahsiyet bu setlerde yer alır. Okuduğu kitaplarda Türk kültüründe öne çıkan isimlerin yaşamlarını, başarılarını görmek çocuklar için güzel bir örnek teşkil edebilir. Kendi kültüründen doğan önemli bir ismi tanımak değerler eğitimi bakımından yararlı olmakla beraber çocuğun gelişim dünyası için ilham verici olabilir. Ayrıca eserlerde bu önemli kişilerin evrensel yönlerine yer verilmesi de çocukların ufuklarının genişlemesine katkı sunabilir.

Türk Edebiyatına ve tasavvuf geleneğine damgasını vuran, Türk dili, edebiyatı ve şiirinin olduğu kadar kültürünün de aslî kurucularından biri Yunus Emre, Türk edebiyatında manevi ve insani kişiliğiyle adından sıklıkla söz ettiren önemli bir şahsiyettir. XIII.-XIV. yüzyıllarda yaşamış Türk-İslam düşünce tarihinin önemli isimlerinden biri olarak insanoğlunu kurtuluşa, huzura, sevgiye ve birliğe götüren gücün koşullar ne olursa olsun insanın kendi içinde ve birikiminde araması gerektiğini, şiirsel bir ustalıkla anlatmaya çalışan kişidir (Karaca, 2020). Tasavvufta "ka'al den çok hal" (söylenilenden ziyade yaşayış) önemlidir. O, ahlaki değerleri yaşama arzusunu gaye edinmiş, büyük bir mutasavvıf' tır. Onun benimsediği ahlaki değerler İslam dininin öğretilerinden beslenen değerlerdir. Yunus insanlara sevmeyi, zarar vermemeyi, kimseyi hor görmemeyi, herkese yardım etmeyi öğütlerken insanlar arasındaki çekişmeleri, topluluklar arasındaki düşmanlıkları ve savaşları anlamsız bulmakta "Biz kimseye kin tutmayız/ kamu alem birdir bize" demektedir. Yunus'a göre insan, dini ve mezhebi ne olursa olsun hangi bütün herkese iyi niyetle bakmalıdır (Demir, 2018). Yaşadığı dönemde Moğol istilası, iç kavgalar, çekişmeler, siyasi otorite boşluğu, kıtlık ve yoksulluklarla Anadolu'nun perişan olduğu yıllardır. Siyasi çekişmelerin yanında farklı inanç ve anlayışların yayılmaya başladığı bir zaman dilimidir. Böylesi bir ortamda, döneminin ilim ve irfan kutuplarıyla birlikte Yunus Emre, 
Allah sevgisini sarsılmaz bir iman ve aşkla dile getirip her türlü bâtıl inanca karşı gerçek İslâm tasavvufunu anlatarak Türk-İslâm birliğinin oluşmasında, çağının ve insanlık çehresinin aydınlanmasında önemli bir rol üstlenmiştir (Karaca, 2020). "Türkçe Yunus Emre'nin kalemiyle bir sevgi ve bilgi dili haline gelmiştir. Yunus, bütün edebiyat tarihimiz içinde Türkçenin edebî bir dil haline gelmesinde en büyük merhalelerden birisidir. Onun dili İslami Türk medeniyetini ve inanç değerlerini bütün derinlikleriyle aksettirmektedir. Gönlünde dalgalanan Allah sevgisini sadrından satırlara geçiren Yunus Emre, şiirine ilahi bir ruh ve ahenk vermiş, onları da adeta söylerken bestelemiştir." (Tatc1, 2015, s.96-96).

Sadece Türk şiirini değil, Anadolu'da oluşan Türk düşüncesini de köklü fikirleriyle derinden etkileyen Yunus Emre (Koca, 2005), gümümüze değin pek çok ilim ve sanat disiplini tarafından farklı yönleriyle irdelenmiştir. Hayatıyla ilgili bilgiler menkıbelerin dışına çıkmasa da tüm belirsizliklere rağmen Yunus Emre sadece yetişkinlerin değil gençlerin ve özellikle çocukların da tanıması, anlaması gereken önemli bir şahsiyettir. Yunus Emre'nin şiirleri, insan sevgisi ve hoşgörü ile örülmüş evrensel felsefesi, açık ve anlaşılır dili çocuklara anlatılmalıdır. Bu doğrultuda çalışmada Yunus Emre'yi anlatan çocuk kitapları belirlenmiş ve bu anlatımın nasıl gerçekleştirildiği değerlendirilmeye çalışılmıştır. Bu araştırmanın amacı; Yunus Emre'yi anlatan çocuk kitaplarının nitelik bakımından ne durumda olduğunu saptayabilmek, Yunus Emre şiirlerinin ve menkıbelerinin çocuk kitaplarında nasıl yer bulduğunu ortaya koymaktır.

\section{Yunus Emre’yi Anlatan Çocuk Kitapları}

Çocuklara ve gençlere Yunus Emre'yi anlatmak için yazılan kitapları belirleyebilmek için geçmişten günümüze çocuk ansiklopedileri, çocuklar için yayın üreten yayınevlerinin katalogları ve internet siteleri üzerinden yapılan alanyazın taraması sonucunda biyografi, hikâye ve şiir seçkisi şeklinde tasarlanmış birçok kitap olduğu görülmüştür. Bu kitaplardan çocuk edebiyatı bağlamında dikkat çekenler kronolojik olarak Tablo 1'de verilmiştir.

Tablo 1. Yunus Emre'yi anlatan çocuk kitapları

\begin{tabular}{|c|c|c|c|}
\hline No. & Eser Ad1 & Yazar Adı & $\begin{array}{l}\text { Basim } \\
\text { Y1li }\end{array}$ \\
\hline 1 & Yunus Emre & Memet Fuat & 1976 \\
\hline 2 & Yunus Emre & Ali Aydoğan & 1987 \\
\hline 3 & Yunus Emre & Muzaffer Uyguner & 1989 \\
\hline 4 & Yunus Emre & Öner Yağcı & 1996 \\
\hline 5 & Yunus Emre (Koza Ünlüler Dizisi içinde) & Koza-Kolektif & 2005 \\
\hline 6 & Yunus Emre'den Şiirler & Timaş Çocuk-Kolektif & 2005 \\
\hline 7 & Yunus Emre & Yuva Yayınları-Kolektif & 2005 \\
\hline 8 & Yunus Emre & Halil İbrahim Yıldırım & 2005 \\
\hline 9 & $\begin{array}{l}\text { Kalp Süvarileri } \\
\text { (Kitapta; Yunus Emre'nin yanı sıra Rabiatül Adaviye, Ebu } \\
\text { Hamid Gazali, Şems, Mevlana, Hallac-ı Mansur, İbrahim } \\
\text { Edhem, İbni Cella, Yusuf b. Hüseyin ve Muhyiddin Arabî } \\
\text { gibi birçok önemli mutasavvıfın hayatına yer verilmiştir.) }\end{array}$ & Münire Daniş & 2006 \\
\hline 10 & Yunus Emre Divanı-Seçme Şiirler & Demet Küçük & 2007 \\
\hline 11 & $\begin{array}{l}\text { Tarihe İz Bırakanlar-Yunus Emre Gel Gör Beni Aşk } \\
\text { Neyledi? }\end{array}$ & Korkut Tankuter & 2008 \\
\hline 12 & Gülün Sırr1-Yunus Emre Hikâyesi & Mustafa Özçelik & 2008 \\
\hline 13 & $\begin{array}{l}\text { Yunus Emre (Tarihi Yeniden Yazan Türk Büyükleri Seti } \\
\text { içinde) }\end{array}$ & $\begin{array}{l}\text { Sevil İnan Sönmez- Yüksel } \\
\text { Yazıcı }\end{array}$ & 2009 \\
\hline 14 & Ben Yunus Emre & Aydoğan Yavaşlı & 2010 \\
\hline 15 & $\begin{array}{l}\text { Ne Demiş Yunus Emre (Ruha Dokunan Düşünceler Serisi } \\
\text { içinde) }\end{array}$ & Fatma Burçak & 2010 \\
\hline 16 & Şiirimizin Süt Dişi Yunus Emre & Salih Zengin & 2010 \\
\hline 17 & Ünlülerle Bir Gün-Yunus Emre’yle Bir Gün & Mustafa Orakçı & 2011 \\
\hline 18 & $\begin{array}{l}\text { Çocuklar için Büyüklerimiz ve Kahramanlarımız-Yunus } \\
\text { Emre }\end{array}$ & Mustafa Akgün & 2012 \\
\hline 19 & Yunus Emre & Ahmet Efe & 2013 \\
\hline 20 & Bizim Yunus & Mustafa Özçelik & 2013 \\
\hline
\end{tabular}


Tablo 1. Yunus Emre'yi anlatan çocuk kitapları (devamı)

\begin{tabular}{llll}
\hline 21 & Yunus Emre (Anadolu Âşıkları Dizisi içinde) & Orhan Yorgancı & 2013 \\
22 & Kültürümüzün Yapı Taşları-Yunus Emre & Behzat Taş & 2014 \\
23 & Sordum Sarı Çiçeğe-Yunus Emre'nin Hayatı ve Şiirleri & Erdem Çocuk & 2014 \\
24 & Yunus Emre & İnci Şahin & 2014 \\
25 & Çizgilerle Kültürümüzün Yapıtaşları-Yunus Emre & Saime Taş & 2015 \\
26 & Sevgi Filozofu Yunus Emre (Eğlenceli Tarih Serisi içinde) & Gülizi Özen & 2016 \\
27 & Ben Yunus Emre (Adam Olmuş Çocuklar-Yıldızlara & Suat Turgut & 2017 \\
& Ulaşmak Serisi 2 içinde) & & 2017 \\
28 & Yunus Emre (Namdar Şairler Serisi içinde) & Hasan Yiğit & 2017 \\
29 & Kahraman Avcısı Kerem'in Not Defteri 5-Kahramanım & İrfan Gürkan Çelebi & \\
& Yunus Emre & & 2018 \\
30 & Yunus Emre Gönül Erleri Serisi-3 & Veli Karanfil & 2019 \\
31 & Yunus Emre (İz Bırakanlar Serisi içinde) & Eda Bayrak & 2020 \\
32 & Yunus Emre-Tarihte İz Bırakanlar & Turan Tektaş & 2020 \\
33 & Çocuk Yüreklerde Yunus Emre-Hayatı ve Şiirleri & Özlem Pekcan & \\
\hline
\end{tabular}

Sonuç olarak; 1960’l1 yıllardan günümüze yani 2020'li yıllara kadar olan süreçte gerek tek bir eser halinde gerekse bir serinin içerisinde Yunus Emre'yi tanıtmak için yazılan kitaplar olduğu görülmüştür. Bu kitaplarda nitelik bakımından Yunus Emre'nin nasıl anlatıldığı, hangi yönlerine yer verildiğinin belirlenmesi gerekli ve önemlidir.

\section{Yöntem}

Araştırma, nitel araştırma desenlerinden tarama ile gerçekleştirilmiştir. "Var olan durumu olduğu şekliyle ortaya koymanın amaçlandığı tarama modelinde araştırmaya konu olan olay, birey ya da nesne kendi koşulları içinde ve olduğu gibi tanımlanmaya çalışılır (Karasar, 2012, s.77).

1960-2020 yılları arasında 50 yıllık süreci ele alarak yapılan alanyazın taraması "Yunus Emre" ve "çocuk kitabı" anahtar kelimeleriyle sınırlandırılmıştır. Çocuklar için basıldığı belirtilmeyen kitaplar çalışmaya dâhil edilmemiştir. Tarama özellikle çocuk ansiklopedileri, çocuk dergileri ve çocuklar için yayın üreten yayınevleri üzerinden gerçekleştirilmiştir. Tarama sonucunda çocuklara Yunus Emre'yi tanıtmak için yazılan 33 kitap belirlenmiştir.

\section{1. İncelenen Eserler}

Yapılan tarama sonucunda farklı yayınevlerinden basılan yedi kitap araştırmada incelen eserleri oluşturmuştur. Eserler, seçkisiz (random) örnekleme yoluyla seçilmiştir. "Özelliklerin normal dağıldığının varsayıldığı durumlarda seçilen seçkisiz örnekleme ile seçilen bir grubun evreni temsil ettiği varsayılır." (Yıldırım ve Şimşek, 2008, s.113). İncelenen eserlerin künye bilgilerine Tablo 2.'de yer verilmiştir.

Tablo 2. İncelenen eserler

\begin{tabular}{|c|c|c|c|c|}
\hline Kitabın Ad1 & $\begin{array}{l}\text { Yazar/ } \\
\text { Hazırlayan }\end{array}$ & $\begin{array}{l}\text { Resimleyen/ } \\
\text { Çizer }\end{array}$ & Yayınevi & Yayın yeri ve yilı \\
\hline $\begin{array}{l}\text { Sordum Sarı Çiçeğe-Yunus } \\
\text { Emre'nin Hayatı ve Şiirleri }\end{array}$ & $\begin{array}{ll}\begin{array}{l}\text { Nuran } \\
\text { (haz.) }\end{array} & \text { Turan } \\
\end{array}$ & Mert Tugen & Erdem Çocuk & $\begin{array}{l}\text { İstanbul, } 2020 \\
\text { (13.bask1) }\end{array}$ \\
\hline $\begin{array}{l}\text { Gülün Sirr1-Yunus Emre } \\
\text { Hikâyesi }\end{array}$ & $\begin{array}{l}\text { Mustafa } \\
\text { Özçelik }\end{array}$ & $\begin{array}{l}\text { Ramila Aliyeva } \\
\text { Gençoğlu }\end{array}$ & Nar Çocuk & $\begin{array}{l}\text { İstanbul, } 2020 \\
\text { (6.bask1) }\end{array}$ \\
\hline $\begin{array}{lll}\text { Yunus } & \text { Emre-Gönül } & \text { Erleri } \\
\text { Serisi-3 } & & \end{array}$ & Veli Karanfil & & Mevsimler Kitap & İstanbul, 2018 \\
\hline Yunus Emre & İnci Şahin & & Mostar & $\begin{array}{l}\text { İstanbul, } \\
\text { (3.bask1) }\end{array}$ \\
\hline $\begin{array}{l}\text { Çocuk Yüreklerde Yunus } \\
\text { Emre-Hayatı ve Şiirleri }\end{array}$ & Özlem Pekcan & Dilara Y1ldız & Dorlion & Ankara, 2020 \\
\hline Sevgi Filozofu Yunus Emre & Gülizi Özen & Enis Temizel & Eğlenceli Bilgi & $\begin{array}{l}\text { İstanbul, } \\
\text { (4.Bask1) }\end{array}$ \\
\hline $\begin{array}{l}\text { Şiirimizin Süt Dişi Yunus } \\
\text { Emre-Türk Büyükleri Serisi } 3\end{array}$ & Salih Zengin & $\begin{array}{l}\text { Dağıstan } \\
\text { Çetinkaya }\end{array}$ & $\begin{array}{lr}\text { İstanbul } & \text { Kültür ve } \\
\text { Sanat } & \text { Ürünleri } \\
\text { Tic.A.Ş. } & \\
\end{array}$ & İstanbul, 2010 \\
\hline
\end{tabular}


İncelenen çocuk kitaplarında yer alması beklenen Yunus Emre menkıbeleri şunlardır:

Alıç ve Kilidinin Anahtarı Menkıbesi: "Yunus, ekincilikle geçinir, yoksul bir adamdı. Bir yıl kıtlık olmuştu, ekin bitmemişti. Hacı Bektaş'ın vasfını o da duymuştu. Gideyim, biraz bir şey istiyeyim dedi. Bir öküze alıç yükledi, vara vara Karaöyük'e geldi, Hünkâr'a, yoksul bir adamım, ekinimden bir şey alamadım yemişimi alın, karşılığını lütfedin ehlimle, ayalimle aşkınıza yiyelim dedi. Hünkâr bir derviş gönderdi, sorun dedi, buğday mı verelim, nefes mi? Yunus'a sordular, ben nefesi ne yapayım, bana buğday gerek dedi. Hünkâr'a bildirdiler. Buyurdu ki: Her alıcın çekirdeği başına on nefes verelim. Yunus'a, bunu söylediler, ehlim var, ayalim var, bana buğday gerek dedi. Bunun üzerine öküzüne buğday yüklediler, yola düştü. Fakat köyün aşağısına gelince hamamın öte yanındaki yokuşu çıkar çıkmaz ne olmayacak iş ettim ben dedi, vilâyet erine vardım, bana nasip sundu, her alıcın çekirdeği başına on nefes verdi, kabul etmedim, verilen buğday birkaç gün yenir, biter. Bu yüzden o nasiplerden mahrum kaldım. Döneyim, tekrar varayım, belki yine himmet eder. Bu fikirle tekrar dönüp tekkeye geldi. Buğdayı indirdi, erenler dedi, bana himmet ettiği nasibi versin, buğday gerekmez bana. Halifeler gidip Hünkâr'a bildirdiler. Hünkâr, o iş, bundan böyle olmaz, o kilidin anahtarını Tapduk Emre'ye sunduk. Ona gitsin, nasibini ondan alsın dedi.” (Gölpınarl1, 2014, s.48).

Düz Odun Menklbesi: "Tabduk Baba sevecen bir yüz ifadesiyle Yunus'a 'De hele bakayım Yunus'der, 'arkadaşların harıl harıl odun taşırken, sen neden eli boş dönersin?' Yunus utanır, sıkılır, gözlerini yere diker. 'Efendim' der, 'dergâhınıza layık düzgün, pürüzsüz bir odun bulamadım!" (Koca, 2005, s.19).

Sofra Menkıbesi: "Yunus Emre, Tabduk Baba dergâhından aldığı izinle yollara düşer. Yolda giderken, bardaktan boşanırcasına bir yağmur başlar. Bir mağarada konaklamak zorunda kalır Yunus. Fakat mağarada yalnız değildir. Bakar ki, kır sakallı yaşı geçkince iki zat ellerini havaya açıp yemek için Allah'a dua eder. Önlerine somun, peynir, zeytin gelir. Onun da dua etmesini isterler. Bunun üzerine Yunus da ellerini havaya açıp başlar duaya. Gözlerini açar sonra. Ne görsün! Mükellef bir Halil İbrahim sofras1. Kerameti gören iki zat hikmetini sorar Yunus'a. 'Ne dua ettin de sana böylesi çeşni bir sofra kuruldu?" derler. Yunus gayet sakin ve mütevazı, "Sizin vesile kıldığınız kişiden talep ettim' der. 'Biz Yunus'tan istemiştik.' der içlerinden biri. Bunun üzerine Yunus hiçbir şey söylemeden çekip gider.” (Koca, 2005, s.20).

Bizim Yunus Menkıbesi: "Kırk yıl Tabduk Baba'ya sabırla hizmet eden Yunus, bâtınî yani gizli ilimleri kendisine açmadığı için şeyhine sitem eder. Bu sitem Tabduk Baba'ya gizli kalmaz. Yunus büyük pişmanlık içinde kendisini şeyhine affettirmek ister. Bu vesileyle şeyhinin eşi Ana Bacı'ya gidip durumunu arz eder. Ana Bacı da bunun üzerine Yunus'a, "Tabduk Emre'nin der, "bilirsin ki gözleri iyicene zayıfladı. Sabah namazına abdest almak için çıkar. Sen de işte o vakit eşiğine yat. Üstüne basınca 'kim o' diye sorar. Ben de 'Yunus' derim. 'Hangi Yunus' derse bil ki gönlünden seni söküp atmış. 'Bizim Yunus mu' derse kapan ayaklarına, dizlerine sarıl, af dile..." Yunus ertesi gece denileni yapıp gün ağarmadan sabaha kadar öylece yatar vaziyet bekler. Tabduk Baba'nın ayağı nihayet gövdesine değer. "Bu kim?" diye sorar eşine. Eşi "Yunus" der. Şeyhi "Bizim Yunus mu?" diye sorunca, Yunus Emre hüngür hüngür ağlayıp ayaklarına kapanır şeyhinin ve kabahatini bağışlatır." (Koca, 2005, s.23).

Söyleyen Yunus Menkıbesi: “Günün birinde Tapduk Emre’ye bir neşe geldi, hallendi. Meclisinde Yûnus-1 Gûyende adlı bir şair vardı, ona, söyle dedi. O, mırın kırın etti, söylemedi. Bu sefer Tabduk Yunus Emre'ye döndü, hadi söyle dedi. Hemen Yunus Emre'nin gözünden bir perde kalktı, söylemeye başladı. Söylediği nefesler büyük bir divan oldu." (Gölpınarlı, 2014, s.48).

Molla Kasım Menkıbesi: "Bir halk rivâyetinde Yunus’un üç bin şiir söylediği fakat bu şiirlerin Mollâ Kâsım adlı bir zahid tarafından şeriata aykırı bulunduğundan dolayı tahrip edildiği işlenir. Mollâ Kâsım şiirleri ele geçirip bir su kenarına oturur. Bin tanesini yakar; bin tanesini de suya atar. Üçüncü bin şiirleri okumaya başlayınca şu beyitlle karşılaşır:Derviş Yunus bu sözü eğri büğrü söyleme/Seni sıgaya çeken bir Molla Kâsım gelir. Beyti okuyan Molla 
Kâsım şaşırır, tevbeye gelir, Yunus'un velayetine inanır. Ne varki iş işten geçmiştir. Elde sadece bin adet şiir kalmıştır.” (Tatc1, 2014, s.26).

Uzun Yazdın Menkıbesi: "Yunus bir gün Mevlana'ya "Mesnevi’yi sen mi yazdın?" demiş. Mevlana "Evet!" deyince "Uzun yazmışsın! Ben olsam; 'Ete kemiğe büründüm/Yunus diye göründüm' derdim, olur biterdi!” demiş. (Gölpınarlı, 2008, s.61).

Dedikodu Menkıbesi: "Yûnus Tapduk'a otuz yıl sadakâtla hizmet etti. Odun taşımaktan sırtı yara oldu. Fakat kimseye belli etmedi. Şeyhi onu severdi. Bu, öbür dervişlere ağır geldi: "Şeyhin kızını seviyor da onun için bu ağır hizmete katlanıyor, dediler. Bu dedikoduyu Tapduk'a duyurdular. (Erkmen, 2014, s.40).

Asâ Menkıbesi: "Yunus feyiz alamadım diye şehirden ayrıldıktan sonra karşılaştıkları dervişlerle başından geçen macera üzerine kendi mertebesini anlamış, şeyhinin büyüklüğünü tasdik ederek dergâha dönmüş ve eşiğine yatarak kendisini affettirmiştir fakat Tapduk, 'Mertebeni öğrendin artık burada duramazsın, asamı attığım yere gider orada ruhunu teslim edersin.' Demiş. Asasını atmış. Yunus bu asayı tam beş sene aramış sonunda Sarıköy'de bulmuş ve orada ölmüş." (Gölpınarlı, 2008, s.61).

\subsection{Verilerin Toplanması ve Analizi}

Çalışma verilerinin toplanması doküman incelemesi ile gerçekleştirilmiştir. "Doküman incelemesi, araştırılması hedeflenen olgu ve olgular hakkında bilgi içeren yazılı materyallerin analizini kapsar." (Yıldırım ve Şimşek, 2008, s.187). Çalışmada incelenen yedi kitaptan elde edilen veriler sınıflandırılarak içerik analizi ile sunulmuştur.

Kitaplarda Yunus Emre'nin nasıl tanıtıldığı dair içerik analizi yapabilmek için Yunus Emre'nin menkıbevi hayatının ve şiirlerinin sunuluşu dikkate alınmıştır. "İçerik analizinde temelde yapılan işlem, birbirine benzeyen verileri belirli kavramlar ve temalar çerçevesinde bir araya getirmek ve bunları okuyucunun anlayabileceği bir biçimde düzenleyerek yorumlamaktır." (Yıldırım ve Şimşek, 2008, s.227).

\section{Bulgular}

Araştırmanın çalışma grubunu oluşturan yedi kitap belirlenen Yunus Emre menkıbelerine ve Yunus Emre şiirlerine yer verme durumlarına göre incelenmiştir. İncelenen kitaplardan elde edilen veriler görsel bir karşılaştırma yapabilmek adına öncelikle tablo halinde sunulmuştur. Kitaplardan yapılan alıntılar ve açıklamalarla bulgular yorumlanmıştır.

Tablo 3. Yunus Emre'nin menkıbevi hayatının ve şiirlerinin sunuluşuna dair bulgular

\begin{tabular}{|c|c|c|c|c|c|c|c|}
\hline Kitaplarda Yer & Sordum & Gülün Sırr1- & Yunus & Yunus & Çocuk & Sevgi & Şiirimizin \\
\hline $\begin{array}{l}\text { Alan Yunus } \\
\text { Emre } \\
\text { Menkıbeleri }\end{array}$ & $\begin{array}{l}\text { Sarı } \\
\text { Çiçeğe- } \\
\text { Yunus } \\
\text { Emre'nin } \\
\text { Hayatı ve } \\
\text { Şiirleri }\end{array}$ & $\begin{array}{l}\text { Yunus } \\
\text { Emre } \\
\text { Hikâyesi }\end{array}$ & $\begin{array}{l}\text { Emre- } \\
\text { Gönül } \\
\text { Erleri } \\
\text { Serisi-3 }\end{array}$ & Emre & $\begin{array}{l}\text { Yüreklerde } \\
\text { Yunus } \\
\text { Emre- } \\
\text { Hayat1 ve } \\
\text { Şiirleri }\end{array}$ & $\begin{array}{l}\text { Filozofu } \\
\text { Yunus } \\
\text { Emre }\end{array}$ & $\begin{array}{l}\text { Süt Dişi } \\
\text { Yunus } \\
\text { Emre-Türk } \\
\text { Büyükleri } \\
\text { Serisi 3 }\end{array}$ \\
\hline $\begin{array}{ll}\text { Alıç } & \text { ve } \\
\text { Kilidinin } & \\
\text { Anahtarı } & \\
\text { Menkıbesi } & \end{array}$ & $\mathrm{X}$ & $\mathrm{X}$ & $\mathrm{X}$ & $\mathrm{X}$ & $\mathrm{X}$ & $\mathrm{X}$ & $\mathrm{X}$ \\
\hline $\begin{array}{l}\text { Düz Odun } \\
\text { Menkıbesi }\end{array}$ & $\mathrm{X}$ & $\mathrm{X}$ & & $\mathrm{X}$ & $\mathrm{X}$ & $\mathrm{X}$ & $\mathrm{X}$ \\
\hline $\begin{array}{l}\text { Sofra } \\
\text { Menkıbesi }\end{array}$ & $\mathrm{X}$ & & & $\mathrm{X}$ & $\mathrm{X}$ & & \\
\hline $\begin{array}{l}\text { Bizim Yunus } \\
\text { Menkıbesi }\end{array}$ & $\mathrm{X}$ & & & $\mathrm{X}$ & $\mathrm{X}$ & & \\
\hline $\begin{array}{l}\text { Söyleyen } \\
\text { Yunus } \\
\text { Menkıbesi }\end{array}$ & $\mathrm{X}$ & $\mathrm{X}$ & & $\mathrm{X}$ & $\mathrm{X}$ & & $\mathrm{X}$ \\
\hline
\end{tabular}


Tablo 3. Yunus Emre'nin menkıbevi hayatının ve şiirlerinin sunuluşuna dair bulgular (devamı)

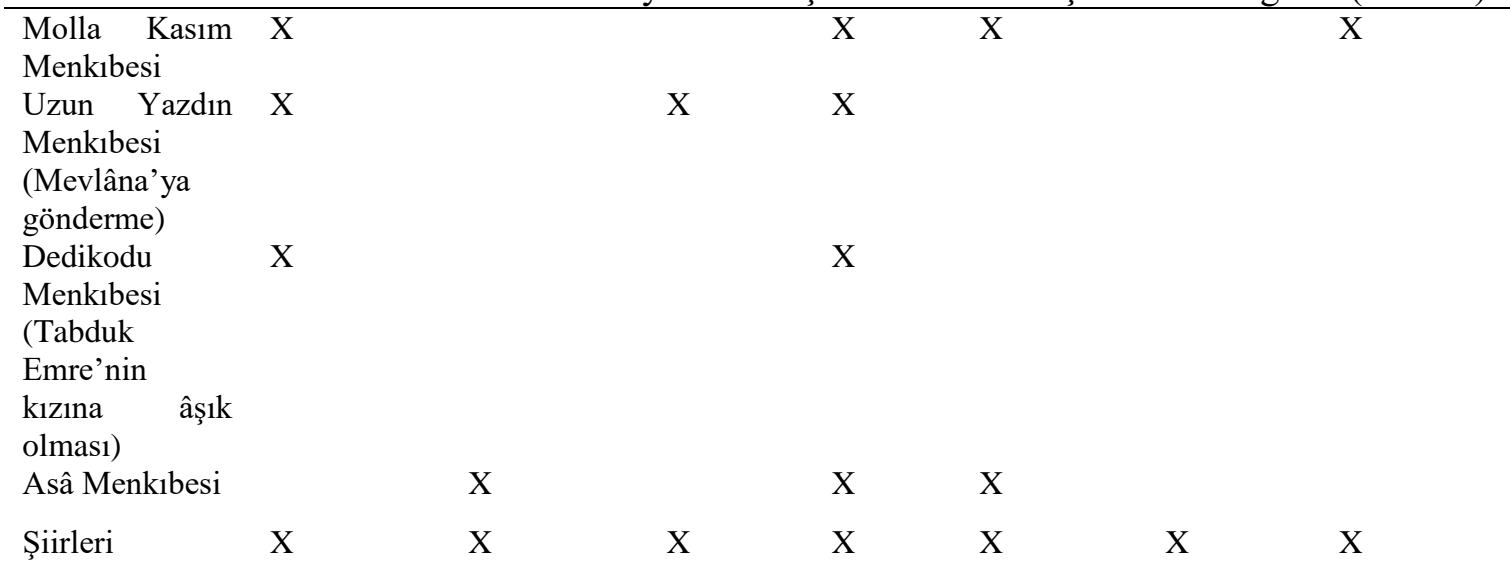

Tablo 3 incelendiğinde; kitapların hepsinde Yunus Emre şiirleri ile Alıç ve Kilidinin Anahtarı menkıbesine yer verildiği görülmektedir. Yunus Emre'nin tasavvufî hayatının başlangıcı olarak kabul edilen bu menkıbe incelenen tüm kitaplarda yer bulmuştur. Kitapların 6'sında Düz Odun, 5'inde Söyleyen Yunus, 4'ünde ise Molla Kasım menkıbelerine yer verilmiştir. Sofra, Bizim Yunus, Uzun Yazdın ve Asâ menkıbeleri ise üçer kitapta yer bulmuştur. En az yer verilen menkıbe Dedikodu menkıbesidir, 2 kitapta yer verildiği görülmektedir.

Sordum Sarı Çiçeğe-Yunus Emre'nin Hayatı ve Şiirleri adlı kitapta; Neslihan Öğretmen ve öğrencilerinin otobüste Yunus ilahileri eşliğinde Yuşa Tepesi'ne doğru yaptıkları piknik yolcuğu ile başlayan anlatı, öğretmenin öğrencilerden Yunus'un hayatını anlatan bir ödev hazırlamalarını istemesiyle gelişir. Öğrenciler Yunus'un hayatına dair ulaştıkları menkıbeleri sınıfta arkadaşlarına sunarlar. Bu anlamda kitabın Yunus'un menkıbevi hayatı üzerine kurgulandığı söylenebilir. Alıç ve Kilidinin Anahtarı menkıbesi "Acaba delikanlı, alıçların karşılığında himmet yerine hikmet istemez miydi?" Yunus düşündü, hikmeti nerede kullanacağını bilemedi. "Himmet isterim!" dedi. (Turan, 2020, s.17) ifadeleriyle yer bulurken Söyleyen Yunus menkıbesi "Ben de seni bekliyordum. Sana bir şey açıklamayışımın tek sebebi, senin kendine inanmamı beklememdir. Senin kendine inanman, çiğliğinin gittiğine delildir. Artık senin kilidin açıld, dilinin çözülüp ilmini dile getirme zamanın getirme zamanın geldi." dedi. Yunus, ondan sonraki bütün meclislerde şiirleriyle herkesi kendine hayran biraktl. (Turan, 2020, s.29) ifadeleriyle aktarılır. Dedikodu menkıbesi "Bu arada, Taptuk Emre'nin dünya güzeli, iyi kalpli kızına da âş̧ı oldu. Fakat duygularını aylarca kimseye anlatamadı. Taptuk Emre, Yunus'un bu hâlini fark etti. Bir süre sonra Taptuk Emre de bu klymetli dervişine kızını nikâhladl. Böylece Yunus sevdiğine kavuştu." (Turan, 2020, s.29) ifadeleriyle verilirken Uzun yazdın menkıbesine dair Mevlana'nın 6 ciltten oluşan Mesnevi'sini uzun bulduğunu söyleyen Yunus Emre'nin "Ben olsam 'Ete kemiğe büründüm, Yunus diye göründüm.'derdim." (Turan, 2020, s.31) ifadeleriyle verilmiştir. Kitapta sadece Asâ menkıbesine yer verilmemiştir. Kitapta ayrıca; annesi Yunus Emre'ye hamileyken babasının rüyasında Ninova halkını doğru yola iletmek için balığın karnından çıkan Yunus peygamberi görmesi ve bir oğlu olacağına ve bu oğulun büyük bir adam olacağı inancı üzerine adını Yunus koyma isteği de menkıbevi şekilde işlenir. Yunus Emre'nin doğumuyla ilgili verilen bu bilgiler Yunus Emre'nin idealize edilmiş bir kahraman, seçkin bir kişi olarak sunulduğu şeklinde de yorumlanabilir. Yunus'un ümmî olması ile ilgiler paylaşıldıktan sonra bunun ermişlik mertebesindeki olgunluk kastıyla söylendiği vurgulanmıştır. Hikâye tarzındaki anlatımda aralarda akışa uygun olarak öğrenciler tarafından okunan Yunus Emre şiirlerine de yer verilmiştir. Anlatıda; sınıftaki öğrenciler sırayla Yunus Emre'den seçtikleri şiirleri okurken iki kardeş arasında atışma yaşanır ve Kağan'ın şiirlerden hareketle çağrışımla bulduğu dil ile ilgili atasözlerinin üzerine Sinan "Dilini eşek arısı soksun!" (Turan, 2020, s.45) diyerek cevap verir. Bu örnek olay üzerinden sevgi ve hoşgörü 
insanı olan Yunus Emre'nin şiirleri işlenirken bu tür hoş olmayan cümlelerin söylenmesine öğretmen üzülür ve öğrencileri uyarır. Kitapta Yunus Emre felsefesi sadece eserlerle değil fikirlerle de aktarılmaya çalışılmıştır. Yunus'un şiirlerinde Allah ve peygamber aşkını işleyişi, bu dünyanın geçiciliğine vurgusu seçilen örnek şiirlerle açıklanır.

Gülün Sırrı-Yunus Emre Hikâyesi adlı kitapta; 10 yaşındaki bir çocuğun yerine göre kendisine anne, baba, öğretmen ve arkadaş kabul ettiği 70 yaşını aşmış olan dedesi ile sohbeti üzerinden sunulan bir Yunus Emre hikâyesine yer verilir. Kitapta Alıç ve Kilidinin Anahtarı menkıbesine şu ifadelerle yer verilir: "Olanı paylaşacağız elbet. Yalnız sana başka bir teklifim var: İstersen buğday yerine himmet (manevi yardım) verelim sana." (Özçelik, 2020, s.46). Söyleyen Yunus menkıbesi ise şu ifadelerle aktarılır: 'Tabduk Emre Yunus Emre için topladığ bir mecliste "Haydi, Yunus sıra sende şimdi. Artık gönlündekini açabilirsin, içindekileri bize saçabilirsin. Konuş, şiirler söyle gönlümüz şenlensin, demiş. Yunus'un içindeki duygular kabardıkça kabarmış. Dili çözülmüşs.' (Özçelik, 2020, s.58-59). Güllere olan düşkünlüğü ve sevgisinden dolayı adı "Gül Baba"ya çıkan dede karakteri "Yunus'umun gülleri" diye bir yandan bahçesindeki gülleri budayarak bakımları ile ilgilenirken diğer yandan şiirler ve Yunus ilahileri okumaktadır. Yunus'umun gülleri ifadesi üzerinden Yunus'un felsefesi verilmeye çalışı1mıştır. 'Yunus, gülün kokusunda, bülbülün ötüşünde Allah'ın mutlak güzelliğini görüp anlayacak bir aydınlık gönüle sahipti. Bu yüzden güle "gül" deyip geçmedi. Allah'ın eseri olarak baktı her şeye." diye açıklama yapan dede, torununun "Peki ya "Yunus'um" sözü?" sorusu üzerine "Yunus, benim, senin, hepimizin! Yüreği sevgiden, inançtan yana olan herkesin.'(Özçelik, 2020, s.66) cevabını verir. Yunus'un şiirlerinden etkilenen çocuk dedesinden kendisine Yunus'un hikâyesini anlatmasını ister. Yunus'un hayatı anlatılırken akışa uygun olarak Yunus Emre şiirlerine de yer verilmiştir. Çocuk karakter Yunus'un hikâyesini dinledikten sonra adeta Yunus'la arkadaş olur. Şiirlerini okumaktan, ezberlemekten ve arkadaşlarıyla paylaşmaktan mutluluk duyar hatta kendi de Yunus gibi şiirler yazmaya heves eder. Çocuk karakterin Yunus Emre'nin şiirlerini bir deftere kaydettiği bilgisini vermesi ve okuyucuların da faydalanabilmesi için seçtiği şiirlere yer verdiğini belirtmesiyle anlatı biter. Anlatının sonunda Yunus Emre'ye ait çok bilinen 11 şiire (Bir Kez Gönül Yıktın ise, Dağlar ile Taşlar ile, İlim İlim Bilmektir vb.) yer verilmiştir.

Yunus Emre-Gönül Erleri Serisi-3 adlı kitapta; Türkçe dersinde Mehmet Öğretmen'in Yunus Emre'den bir şiir okumasıyla anlatı başlar. Bu anlamda metin içinde Yunus Emre şiirine yer verildiği söylenebilir. Sınıftaki öğrenciler içinde sadece Dedesi Yunus Efendi'den Yunus Emre şiirlerini dinlemeye aşina olan Burak şiiri açıklayabilir. Bunun üzerine öğretmen tüm sınıftan Yunus Emre'nin hayatını anlatan bir araştırma ödevi hazırlamalarını ister. Burak, babası Salih Bey ve dedesi Yunus Emre Divanı ve ona dair yazılan birkaç kitap eşliğinde Burak'ın ödevi için sohbete koyulurlar. Yunus'un kendi şart ve imkânları dâhilinde iyi bir eğitim görmesinden, Divan ve Risaletü'n Nuhiyye adlı eserlerinden, alçakgönüllülüğünden, kendini ve Allah'1 bilme çabasından, sevgi insanı olduğundan, şefkat ve merhamet içerikli şiirler yazdığından bahsedilmiştir. Kitapta Alıç ve Kilidinin Anahtarı menkıbesine şu ifadelerle yer verilir: "Hacı Bektâş-ı Veli Yunus'a, buğday yerine manevi ilimleri, yani nefes vermeyi teklif eder." (Karanfil, 2018, s.46). "Anadolu insanı o kadar sever, benimser ve kendisiyle özdeşleştirir ki onun kendi köyünde, kasabasında ve şehrinde yaşamış olduğunu düşünür ve ister." (Karanfil, 2018: 88) ifadeleriyle ise Yunus'un Anadolu'nun değişik köy, kasaba ve kentlerinde mezarı olduğu bilgisine yer verilmiştir. Kitap on dört başlıktan/bölümden oluşmaktadır. Kitabın kurgusunu ise on iki bölüm oluşturur ve bu bölümlerin her birinin sonunda kitabın yazarına ait olan çoğu Yunus Emre ve tasavvuf anlayışı ile ilgili şiirlere yer verilmiştir. Son iki başlıkta ise "Yunus Emre Şiirlerinden Örnekler" (Çağırayım Mevlam Seni, Söz Ola gibi çok bilinen 7 şiiri ve Risaletü'n Nushiyye'den bir bölüm) ve "Yunus Emre İçin Yazılan Şiirlerden Örnekler" (Necip Fazıl Kısakürek, Rıza Tevfik Bölükbaşı, Halide Nusret Zorlutuna, Halit Fahri Ozansoy, Ahmet Kabaklı, Abdullah Odabaş şiirleri) yer alır. 
Yunus Emre adlı kitapta; Yunus Emre'nin hayatı, bölüm başlarında yerli ve yabancı isimlerden (Burhan Toprak, Samiha Ayverdi, Sezai Karakoç, İbrahim Hakkı, Annemarie Schimmel gibi) onun felsefesine yakın tasavvufi söylemlerle metin içinde ise onun için yazılan şiirlere (Necip Fazıl Kısakürek'in yazdığı şiir gibi) ve kendi şiirlerinden alıntılara yer verilerek aktarılmıştır. Kitapta araştırmada belirlenen tüm menkıbelere yer verilmiştir. Örnek vermek gerekirse; Söyleyen Yunus menkıbesi şu ifadelerle yer bulmuştur: 'Tapduk, Yunus'un suskunluğunun ardında sakladiğl şeyin en değerli şeyi olduğunu biliyordu. Yunus konuştuğunda gerçekten konuşuyordu. Kelime israf etmeden, lafi döndürüp dolaştırmadan, ipe inci dizer gibi dikkatle söze yol veriyordu. Yunus söylediğinde, kurt, kuş, cümle mürit sus pus dinliyordu. Yunus zamanla dergâh sohbetlerinin vazgeçilmezi oldu. O olduğunda; sesi nağme olup meydan doldurduğunda, sohbete bir başka feyz yayllyyordu. Tabduk Yunus'a "söyle" diyor, Yunus sesini aşka bırakıp Tapduk'un gönül sohbetinin girizgâhı, ilhamı oluyordu.' (Şahin, 2018, s.67). Kitapta dedikodu menkıbesine de yer verilir. Yunus şeyhi Tabduk Emre'nin kızına âşık olur, hakkında bu aşk için şeyhine hizmet ettiği dedikoduları çıkar. Yunus bu dedikodulara, kötü sözlere öfkelenmez, kendince nükteye vurur, niyetiyle mücadeleye girişir ve en sonunda "Ben şeyhimin kızına layık değilim!" (Şahin, 2018, s.71) der. Yunus'un Tabduk Emre'den ayrılıp kendi yoluna gidişi Asâ menkıbesi ile şu şekilde anlatılır: "Yunus, artık vaktin erişmiştir. Allah'a tamam kavuşmanın günü gelmiştir. İşte ben, elimdeki asayı atıyorum. Seğirt peşinden git. Seni bulacağı güne kadar gökte dolaşsın ... Her nereye düşerse, orada ruhunu teslim et. Var git Tanr ile 'bir' ol." (Şahin, 2018, s.104). Biyografi dizisi içerisinde yer alan kitabın dilinin incelenen diğer eserlere göre daha edebî olduğu görülmüştür. Çocuk edebiyatının yanı sıra ilk gençlik edebiyatı eserleri arasında yer alabilecek niteliktedir. Yunus'un kendinden bahsederken şair veya ozan yerine kendini insana daha yakın, daha mesafesiz kılan derviş, miskin, âşık sıfatlarını kullanmasına değinilmiştir. Yunus'un inceliklerle dolu mükemmel dilinden, açıkça söyleyiş üzerindeki çabasından, hiçbir iltifatın veya makamın peşinde olmayışından bahsedilmiştir. Risaletü'n Nushiyye eseri hakkında bir başlık açılmış ve bilgi verilmiştir. Yunus $\mathrm{Ne}$ Hoş Demişsin başlığı ile biten anlatının ardından Yunus şiirlerine ve Risaletü'n Nushiyye'den bir parçaya yer verilmiştir. Yunus'un mana arayışına, Anadolu'nun yoksul ve yangın yeri şeklindeki halinde kendini görmesine, söylediği sözlerin arkasında Allah sözleri, ayetleri olduğuna değinilmiştir. Birçok yerde Yunus'un mezarı olduğu bilgisi de kitapta şu ifadelerle yer alır: 'Anadolu'nun birçok yerinde Yunus adına türbeler yapıldl. Eskişsehir'de; Mihalıç̧ı, Karaman, Manisa, Erzurum, Afyon, Isparta, Aksaray, Ordu, Yunus'un topraklarında yattığını iddia etti.Yunus için her biri bir kabir yaptırd, yahut meçhul bir mezara "Yunusundur" dedi. Yunus'a dağ taş Anadolu "bizimdir" dedi.' (Şahin, 2018, s.148).

Çocuk Yüreklerde Yunus Emre-Hayatı ve Şiirleri adlı kitapta; anlatı içinde uygun yerlere Yunus'un şiirleri yerleştirilmiştir. Böylece Yunus'un sadece hayatı değil üslubu da aktarılmıştır. Kitapta Söyleyen Yunus menkıbesi şöyle aktarılır: 'Anlatırlar ki; 40 yll odun taşımış tekkesine Yunus. Derken bir gün Anadolu Erenleri, Dergâhı ziyarete gelmişler. Onlar için kurulmuş mecliste söyleşmeye başlamışlar. Bunlar arasında Guyende önadını taşır bir Yunus daha varmış. Sohbetin derinliğinden coşkuya kapılan Tapduk Emre işte o Yunus'a hitaben: "Söyle Yunus," demiş. Ne ki tek kelime çıkmamış bunun ağzından. Pîr yinelemiş: "Söyle!" Yine ses yok. Bunun üzerine bizim Yunus'a dönmüş Tabduk Emre ve buyurmuş: "Sen söyle!” Bu buyrukla Yunus'un gönlünün kilidi açılmış, gözünün perdesi kalkmış sanki.' (Pekcan, 2020, s.29). Asâ menkıbesi de Tabduk'un asayı firlatması ve Yunus'un Sarıköy'e yerleşmesi (Pekcan, 2020, s.59) şeklinde açıklanır.

Sevgi Filozofu Yunus Emre adlı kitapta; karikatürler eşliğinde Yunus Emre'nin hayatı işlenmektedir. Bilgi Kutusu ve Meraklısına Notlar adı verilen bölümlerde konulara uygun açıklayıcı bilgiler yer almaktadır. Soru-cevap bölümlerinde anlatılanlar pekiştirilirken konuya uygun karikatürlerle kitap tekdüzelikten çıkarılmış ve kitabın sıkılmadan okunması sağlanmıştır. Eğlenceli Tarih serisinde yer alan kitapta Yunus Emre'nin sevgi dolu anlayışına yer verilmiştir: Yunus Emre'ye göre sevgi her yerde ve her şeyde. Sevgi her şeyin kaynağl. Çünkü sevgi Yaradan'dan geliyor. Bu muhteşem güç, yaratılan her şeyde var. Yunus Emre bu 
eşsiz gerçekliği görüyor ve şu değerli sözü söylüyor: "Yaradılanı severim, Yaradan'dan ötürü." (Özen, 2020, s.32). İyilik, hoşgörü, alçakgönüllülük, anlayış, saygı, güzellik ve aşk kavramları üzerinden Yunus Emre'nin olaylara bakışına, özelliklerine yer verilmiştir. Ayrıca "Yunus Emre'nin Felsefesi” başlı̆̆ altında yine Yunus Emre'nin tüm insanlığı kucaklayan sevgi anlayışına değinilmiştir. Çocukların dikkatini çekecek şekilde Yunus Emre'nin isminde saklı bir sır gibi Emre kelimesinin "âşık" anlamına geldiği bilgisine yer verilmiş ve bu ismin bir halk ozanı için çok uygun olduğu vurgusu yapılmıştır. Divan ve Öğütler Kitabı olmak üzere iki önemli eseri hakkında bilgi verilmiştir. Diğer eserlerde Risaletü’n Nushiyye olarak eserin orijinal adına doğrudan yer verilirken bu kitapta çocuklar için daha anlaşılır olması amacıyla eserin Türkçe karşılığının verildiği, açıklanırken orijinal ismine değinildiği görülmektedir. Yunus Emre'nin Anadolu'da Türkçe şiir dilinin öncüsü olduğuna vurgu yapılmıştır. Şiirlerinde birçok halk deyimi ve kavramına yer vermesi, öz Türkçe kelimeler kullanması, yalın anlatımı ve evrensel sevgi felsefesiyle yazması, şiirlerinin bestelenerek ilahiye dönüşmesi üzerinde durulmuştur. Ayrıca Yunus Emre şiirlerinin Türkiye'nin ilk oratoryosuna dönüştüğü bilgisi verilir. Kitap bir etkinlik alanı gibi de tasarlanmıştır ve bazı bölümlerde (Örn. s.76, s.96, s.98, s.102, s.129-130) kurgu ile ilgili olarak hem bilgi hem bulmaca odaklı yazma alanlar1 oluşturulmuştur. Öğrencilere birkaç satırlık boşluklar bırakılarak onlardan bu alanlara belirli şeyler yazmaları istenmiştir. Yine soru sorularak çoktan seçmeli şıklar sunulmuş (s.109, s.110, s.123, s.132), bilmecelere yer verilmiş (s.117, s.118) ve okuyucu düşündürülmüştür. Yunus Emre'nin günümüzde birçok türbesi olduğu ve bu türbelerin birçok ülkeden ziyaretçisinin olduğu bilgisinin ardından Yunus Emre Türbeleri; Eskişehir'in Mihalıççık ilçesine bağlı Sarıö̈y, Karaman'daki Yunus Emre Türbesi, Ünye; Kula'da Emre köyü, Erzurum Tuzcu (Dutçu) köyü, Isparta'nın Gönen ilçesi, Afyon'un Sandıklı ilçesi, Tokat'ın Niksar ilçesi, Azerbaycan'ın Şeki şehri, Bursa'daki Âşık Yunus Hazretleri Türbesi (s.86-87) detaylı bir şekilde anlatılmıştır. Dünya çapında bir değer olduğu vurgulanmış, Viyana'daki Yunus Emre Çeşmesi ve Türkmenistan'daki Yunus Emre Heykeli örnek verilmiştir. UNESCO tarafından ünlü şairin doğumunun 750. yıldönümü olan 1991 yılını bütün dünyaya Yunus Emre Sevgi Yılı ilan edilmesi bilgisi aktarılmıştır. Her yıl Eskişehir'de düzenlenen Uluslararası Yunus Emre Kültür ve Sanat Haftası etkinlikleri hakkında bilgi verilmiştir. Akademisyenlerle konferanslar, kaligrafi sergileri, şiir ve ilahi dinletileri, tiyatro oyunları, söyleşiler, Yunus Emre'nin köyüne "Sevgi Treni" ile yolculuk imkânı bu etkinlikler arasındadır ve Yunus Emre'yi merak eden çocukların katılmak isteyebilecekleri ilgi çekici bilgilerdir. Az da olsa bazı yerlerde Yunus Emre'nin şiirlerine ve dörtlüklerine (s.101, s.162) yer verilmiştir. "Yunus Emre'den Ögütler" başlı̆̆ ile şaire ait özlü sözlere yer verilmiştir.

Şiirimizin Süt Dişi Yunus Emre Türk Büyükleri Serisi 3 adlı kitapta; metin içinde bazı yerlerde Yunus Emre'den dörtlüklere yer verilmiştir. Soğuk bir kış gününde şömine başında dedesinin torununa Yunus Emre dizeleri okuması ile kurguya giriş yapılır. Dedesi anlatırken çocuk karakter kendini o dönemde, tarihin içinde ve Yunus Emre'nin yanında bulur. Molla Kasım menkıbesi şu ifadelerle verilmiştir: Eline aldiğı son deste kâğldın ilkini okumaya başladiğı an donmuş bir halde kallyor adeta. Yüksek sesle bir kere daha okuyor: "Derviş Yunus sözü bu/Eğri büğrü söyleme/Seni sigaya çeker/Bir Molla Kasim gelir.” (Zengin, 2010, s.18).

\section{Tartışma, Sonuç ve Öneriler}

Türk kültürünün yetiştirdiği büyük değerlerden biri olan Yunus Emre öz Türkçe şiir dili ve tüm insanlığ kucaklayan sevgisi ile çağının ötesine geçmeyi başarmış bir şahsiyettir. Bu araştırmada incelenen Yunus Emre'yi anlatan çocuk kitaplarının hepsinde Yunus Emre dünyaya geldiğinde Anadolu halkının içinde bulunduğu zor şartlara, yoksulluğa değinilmiştir. Unutulmaz Yunus şiirlerine, insan sevgisine ve mezarının birçok ilimizde olduğuna dair bilgilere de yer verilmiştir. Yine tüm kitaplarda Hacı Bektaş kapısından alınamayan himmetin Tabduk Emre kapısında bulunduğu bilgisi Alıç ve Kilidinin Anahtarı menkıbesi ile aktarılmıştır. Kitapların çoğunda Yunus Emre'nin dergâha düz odun taşıdığını aktaran Düz Odun menkıbesi ve Tabduk Emre'nin izniyle dile gelerek şiirler söylemeye başladığı Söyleyen Yunus menkıbesi yer 
almıştır. Molla Kasım'ın Yunus'un şiirlerini nehre atmasına dair menkıbe kitapların yarısından fazlasında yer alırken Sofra, Bizim Yunus, Uzun Yazdın ve Asâ menkıbeleri ise daha az kitapta yer bulmuştur. En az yer verilen menkıbe Dedikodu menkıbesidir. Görülmektedir ki Yunus Emre'nin menkıbevi hayatı bilinmezlerle dolu hayatının anlatımını kolaylaştırmak ve çocukların dikkatini çekecek şekillerde kurgulara yerleştirilerek sunulmuştur. Kitapların çoğunda Risaletü’n Nushiyye hakkında bilgi verilmiş, şair eserleriyle de tanıtılmaya çalışılmıştır.

Karaca (2020) çalışmasında; Yunus Emre'nin hayatını işleyen biyografik romanlarda menkıbevi malzemenin hep öne çıktığını, roman kahramanı Yunus Emre'nin küçük yaşlardan itibaren arayış içinde olduğunu, huzursuz ama meraklı, varlık-yokluk üzerine düşünen bir kişilik sergilediğini belirlemiştir. Araştırmacıya göre romanlarda Yunus; ne aradığını bilmeyen, özlem, yalnızlık, ölüm korkusu, taşkınlık ve sevgi ekseninde yaşayan bir karakterdedir. Bu çalışmada incelenen kitaplarda da benzer şekilde Yunus Emre'nin yaşamının menkıbevi bilgilere yer verilerek anlatıldığı ve ayıca çocukların özdeşim kurmasını kolaylaştırmak adına kurgulara çocuk karakterlerin eklendiği görülmüştür. Yunus'u çocuklara anlatan yetişkin karakterlere özellikle dede ve öğretmen- yer verilmiştir. Yunus Emre felsefesi sadece eserleriyle değil fikirleriyle de aktarılmaya çalışılmıştır. Yunus Emre'nin dönem itibariyle yaşadığı yoksulluk ve kendini bulma çabası, sevgisinin genişliği üzerinde durulmuştur.

Kurt (2019), Yunus Emre konulu romanlarda kurgu oluşturulurken Yunus Emre'nin hayatı ve şahsiyetiyle ilgili menkıbeler ve şiirler olmak üzere iki önemli kaynaktan yararlanıldığını belirtir. Araştırmacıya göre; menkıbeler özellikle romanın olay örgüsünü biçimlendirmek için kullanılırken, şiirlerden ise ana epizotlar içerisinde olay birimcikleri şekillendirmek için istifade edilir. Araştırmacının tespitlerine göre romanlarda; bazen şiirin tamamına, bazen birkaç beyite/dörtlüğe yer verilmiş, bazen de şiirler değiştirilerek yeni cümleler halinde yazılmıştır. Romanlarda şiirlerin tamamı veya birkaç dörtlüğün bir arada verildiği örneklere sıklıkla rastlandığını fakat bu tarz kullanımların romanlara edebî ve estetik açısından pek bir şey katmadığını ifade eden yazar; mısra ve beytin aynen alınması veya biraz değiştirilerek romana dâhil edilmesinin kurgu açısından daha doğru bir teknik olduğunu vurgular. Bu araştırmada da benzer şekilde anlatının kurgusal akışını oluşturmakta Yunus Emre ile ilgili menkıbelerden yararlanıldığı ve akışa uygun olarak -yoğunlukları değişmekle beraberşairin şiirlerine, şiirlerinden alınan beyitlere/dörtlüklere ve Yunus Emre için başka şairler tarafından kaleme alınan şiirlere yer verildiği görülmüş̧ür. Menkıbeler anlatıma derinlik katarken, şiirler ve şiir parçaları sayesinde estetik bir üslup yakalanmıştır.

Sonuç olarak; Yunus Emre'yi anlatan çocuk kitaplarının şairin menkıbevi hayatına ve şiirlerine yer verilerek hazırlandığ ögesinin devindirildiği ve şiir dizeleri ile anlatımın akıcılığının sağlandığg söylenebilir. Çocuk edebiyatı ürünlerinde iç yapı özellikleri kadar dış yapı özellikleri de önem taşımaktadır. Bundan sonraki çalışmalarda Yunus Emre'yi anlatan kitapların dış yapı özellikleri bakımından (resimleme, boyut, kâğıt cinsi vb.) incelenmesi önerilebilir. İncelenen kitapların hangi yaş aralığındaki çocuklar için uygun olduğu belirtilmemiştir ve kitaplardan sadece biri (Sevgi Filozofu Yunus Emre) Yunus Emre'nin hayatı karikatürler eşliğinde ve eğitici bilgilere yer verilerek sunulmuştur. Çocukların ilgilerini çekebilecek, eğlenirken yeni bilgiler edinebilecekleri kitapların daha etkili olduğu düşünüldüğünde Yunus Emre'yi anlatmak için yayınevleri tarafından çıarılacak yeni kitapların nitelik ve nicelik olarak geliştirilmesi, kitapların hangi yaş aralığına uygun olduğunun belirtilmesi önerilebilir.

\section{Kaynakça}

Demir, R. (2018). Yunus Emre divanında değerler eğitimine dair motifler. Meydan, H. (Ed), Toplumsal Bütünleşmede Değerler ve Eğitimi III. Uluslararası Değerler Eğitimi Kongresi Bildiriler Kitabı içinde, (s.181-193). ISBN: 978-605-9678-18-6 
Erkmen, A. (2014). Yûnus Emre'nin hayatını konu alan biyografik romanlar (Yayımlanmamış yüksek lisans tezi). Ahi Evran Üniversitesi, Kırşehir.

Gökşen, E. N. (1980). Örnekleriyle çocuk edebiyatımız. İstanbul: Remzi Kitabevi.

Gölpınarl1, A. (2008). Yunus Emre ve tasavvuf. İstanbul: İnkılap Kitabevi.

Gölpınarlı, A. (2014). Manâkıb-ı hünkâr hacı bektâş-ı veli, vilâyet-nâme. İstanbul: İnkılâp Kitabevi.

Karaca, N. (2020). Tarihi-Biyografik niteleme ışığında çağdaş dönem yunus emre romanları, https://www.tyb.org.tr/prof-dr-nesrin-karaca-tarihi-biyografik-niteleme-isiginda-cagdasdonem-yunus-emre-rom-42681h.htm (Erişim Tarihi: 15.05.2021).

Karanfil, V. (2018). Yunus emre-gönül erleri serisi-3. İstanbul: Mevsimler Kitap.

Karasar, N. (2012). Bilimsel araştırma yöntemi. Ankara: Nobel.

Koca, O. (2005). Yunus Emre divanı'ndan seçmeler. Ankara: Beyan Yayınları.

Kurt, S. (2019). Yunus Emre konulu romanlarda Türk halk kültürü unsurları (Yayımlanmamış yüksek lisans tezi). Ondokuz Mayıs Üniversitesi, Samsun.

Özçelik, M. (2020). Gülün sırrl-yunus emre hikâyesi. İstanbul: Nar Çocuk.

Özen, G. (2020). Sevgi filozofu yunus emre. İstanbul: Eğlenceli Bilgi.

Pekcan, Ö. (2020). Çocuk yüreklerde yunus emre-hayatı ve şiirleri. Ankara: Dorlion.

Sever, S. (2007). Çocuk ve edebiyat. Ankara: Kök Yayıncılık.

Şahin, İ. (2018). Yunus emre. İstanbul: Mostar.

Şirin, M. R. (2007). Çocuk edebiyatına eleştirel bir bakış "Çocuk edebiyatı nedir ne değildir?”. Ankara: Kök Yayıncıllk.

Tanju, E. H. (2013). Edebi türler açısından çocuk edebiyatı. Çocuk Edebiyatı içinde, s.93-158, Ed.: M. Gönen, Ankara : Eğiten Kitap.

Tatc1, M. (2014). Yunus Emre divan-ı ilahiyat. (3.Bask1). İstanbul: H Yayınları.

Tatc1, M. (2015). Yûnus Emre ile aşk yolculuğu, hayatı ve seçme şiirleri. İstanbul: H Yayınları.

Temizyürek, F., Şahbaz, N.K., Gürel, Z. (2016). Çocuk edebiyatı. Ankara: Pegem Akademi.

Turan, N. (2020). Sordum sarı çiçeğe-Yunus Emre'nin hayatı ve şiirleri. İstanbul: Erdem Çocuk.

Yalçın, A. \& Aytaş, G. (2011). Çocuk edebiyatı. (5.Baskı). Ankara: Akçă̆g.

Yıldırım, A. \& Şimşek H. (2008). Sosyal bilimlerde nitel araştırma yöntemleri. Ankara: Seçkin Yayıncilik.

Zengin, S. (2010). Şiirimizin süt dişi yunus emre-Türk büyükleri serisi 3. İstanbul: İstanbul Kültür ve Sanat Ürünleri Tic.A.Ş.

ETIKK ve BİLIMSEL İLKELER SORUMLULUK BEYANI

$\mathrm{Bu}$ çalışmanın tüm hazırlanma süreçlerinde etik kurallara ve bilimsel atıf gösterme ilkelerine riayet edildiğini yazar(lar) beyan eder. Aksi bir durumun tespiti halinde Afyon Kocatepe Üniversitesi Sosyal Bilimler Dergisi'nin hiçbir sorumluluğu olmayıp, tüm sorumluluk makale yazarlarına aittir.

\section{ARAŞTIRMACILARIN MAKALEYE KATKI ORANI BEYANI}

1. yazar katk1 oranı : \%100 